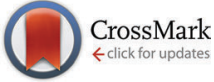

Cite this: New J. Chem., 2015 39, 7595

Received (in Montpellier, France) 5th March 2015 ,

Accepted 14th April 2015

DOI: 10.1039/c5nj00555h

www.rsc.org/njc

\title{
Synthesis and catalytic activity of homoleptic lanthanide-tris(cyclopropylethinyl)amidinates $\$$
}

\begin{abstract}
Farid M. Sroor, Cristian G. Hrib, Liane Hilfert, Sabine Busse and Frank T. Edelmann*
Reactions of anhydrous lanthanide trichlorides, $\mathrm{LnCl}_{3}(\mathrm{Ln}=\mathrm{Nd}, \mathrm{Sm}, \mathrm{Ho})$, with 3 equiv. of lithiumcyclopropylethinylamidinates, Li[C- $\left.\mathrm{C}_{3} \mathrm{H}_{5}-\mathrm{C} \equiv \mathrm{C}-\mathrm{C}(\mathrm{NR})_{2}\right]$ (1a: $\mathrm{R}=$ cyclohexyl (Cy), $\mathbf{1 b}: \mathrm{R}={ }^{\mathrm{i}} \mathrm{Pr}$ ), afforded the new homoleptic lanthanide(III) tris(cyclopropylethinylamidinate) complexes $\left[\mathrm{C}-\mathrm{C}_{3} \mathrm{H}_{5}-\mathrm{C} \equiv \mathrm{C}-\mathrm{C}(\mathrm{NCy})_{2}\right]_{3} \mathrm{Sm}(\mathbf{2 a})$ and $\left[\mathrm{C}-\mathrm{C}_{3} \mathrm{H}_{5}-\mathrm{C} \equiv \mathrm{C}-\mathrm{C}\left(\mathrm{N}^{i} \mathrm{Pr}\right)_{2}\right]_{3} \mathrm{Ln}(\mathrm{Ln}=\mathrm{Nd}(\mathbf{2 b}), \mathrm{Sm}(\mathbf{2 c}), \mathrm{Ho}(\mathbf{2 d}))$ as air- and moisture-sensitive crystalline solids in moderate to good isolated yields (45-79\%). The formation of unsolvated, homoleptic Ln(III) tris(cyclopropylethinylamidinate) was confirmed by an $\mathrm{X}$-ray diffraction study of the holmium derivative $\left[\mathrm{c}-\mathrm{C}_{3} \mathrm{H}_{5}-\mathrm{C} \equiv \mathrm{C}-\mathrm{C}\left(\mathrm{N}^{i} \mathrm{Pr}\right)_{2}\right]_{3} \mathrm{Ho}(\mathbf{2 d})$. El mass spectra of the new rare-earth metal amidinates indicated a significant volatility. An initial catalysis study revealed that these complexes catalyze the addition of terminal alkynes to carbodiimides to give propiolamidines of the type $\mathrm{R}-\mathrm{C} \equiv \mathrm{C}-\mathrm{C}\left(=\mathrm{NR} \mathrm{R}^{\prime}\right)\left(N H R^{\prime}\right)$. The molecular structure of $N, N^{\prime}$-dicyclohexyl-phenylpropiolamidine, $\mathrm{Ph}-\mathrm{C} \equiv \mathrm{C}-\mathrm{C}(\mathrm{NCy})(\mathrm{NHCy})(\mathbf{4})$, was also determined by $\mathrm{X}$-ray diffraction.
\end{abstract}

\section{Introduction}

In organolanthanide chemistry, steric saturation of the coordination sphere of the large rare-earth metal cations is generally more important than the electron count. Thus the investigation of new spectator ligands which satisfy the coordination requirements of the lanthanides continues to be of significant current interest. Anionic amidinate ligands of the type $\left[\mathrm{RC}\left(\mathrm{NR}^{\prime}\right)_{2}\right]^{-}(\mathrm{R}=\mathrm{H}$, alkyl, aryl; $\mathrm{R}^{\prime}=$ alkyl, cycloalkyl, aryl, $\mathrm{SiMe}_{3}$ ) have been demonstrated to be highly useful and versatile in that respect. These readily available $\mathrm{N}$-chelating ligands are generally regarded as steric cyclopentadienyl equivalents. ${ }^{1}$ In the case of rare-earth metals, mono-, di- and trisubstituted lanthanide amidinate and guanidinate complexes are all accessible, just like the mono-, di- and tricyclopentadienyl complexes. Over the past $c a .25$ years, lanthanide amidinates have witnessed an impressive transformation from laboratory curiosities to highly active homogeneous catalysts as well as valuable precursors in materials science. Various rare-earth metal amidinates have been reported to be very efficient homogeneous catalysts $e . g$. for ring-opening polymerization reactions of lactones, the guanylation of amines or the addition of terminal alkynes to carbodiimides. $^{2}$ In materials science, homoleptic alkyl-substituted lanthanide tris(amidinate) complexes are often

Chemisches Institut der Otto-von-Guericke-Universität Magdeburg,

Universitätsplatz 2, 39106 Magdeburg, Germany. E-mail: frank.edelmann@ovgu.de; Fax: +49 391 671-2933; Tel: +49 391 675-8327

$\dagger$ Dedicated to Professor Herbert W. Roesky on the occasion of his 80th birthday. \$ Electronic supplementary information (ESI) available: CIF files of the X-ray structural data for 2d and 4. CCDC 1050915 (2d) and 1050916 (4). For ESI and crystallographic data in CIF or other electronic format see DOI: 10.1039/c5nj00555h highly volatile and can be used as promising precursors for ALD (atomic layer deposition) and MOCVD (metal-organic chemical vapor deposition) processes, e.g. for the deposition of lanthanide oxide $\left(\mathrm{Ln}_{2} \mathrm{O}_{3}\right)$ or lanthanide nitride ( $\left.\mathrm{LnN}\right)$ thin films. ${ }^{3}$

The introduction of alkinyl groups to the central carbon atom in amidines leads to alkinylamidines (or propiolamidines) of the type $\mathrm{R}-\mathrm{C} \equiv \mathrm{C}-\mathrm{C}\left(=\mathrm{NR}^{\prime}\right)\left(\mathrm{NHR}^{\prime}\right)$. In organic synthesis, alkinylamidines have been frequently employed in the preparation of various heterocycles. ${ }^{4,5}$ More recently, alkinylamidines have attracted considerable attention due to their diverse applications in biological and pharmacological systems. ${ }^{6}$ Moreover, transition metal and lanthanide alkinylamidinate complexes have been shown to be efficient and versatile catalysts $e . g$. for $\mathrm{C}-\mathrm{C}$ and $\mathrm{C}-\mathrm{N}$ bond formation, the addition of $\mathrm{C}-\mathrm{H}, \mathrm{N}-\mathrm{H}$ and $\mathrm{P}-\mathrm{H}$ bonds to carbodiimides as well as $\varepsilon$-caprolactone polymerization. ${ }^{7}$ Thus far, only very few lanthanide complexes containing alkinylamidinate ligands have been described. ${ }^{7,8}$ Previously used propiolamidinate ligands include e.g. phenylethinyl derivatives $\left[\mathrm{Ph}-\mathrm{C} \equiv \mathrm{C}-\mathrm{C}(\mathrm{NR})_{2}\right]^{-}\left(\mathrm{R}={ }^{\mathrm{i}} \mathrm{Pr},{ }^{t} \mathrm{Bu}\right)^{7 a, 8}$ and the trimethylsilylacetylene-derived anions $\left[\mathrm{Me}_{3} \mathrm{Si}-\mathrm{C} \equiv \mathrm{C}-\mathrm{C}(\mathrm{NR})_{2}\right]^{-}(\mathrm{R}=$ cyclohexyl (Cy), $\left.{ }^{\mathrm{i}} \mathrm{Pr}\right){ }^{9}$

In the course of our ongoing investigation of lanthanide amidinates we recently initiated a study of alkinylamidinates derived from cyclopropylacetylene. The resulting anions $\left[\mathrm{c}-\mathrm{C}_{3} \mathrm{H}_{5}-\mathrm{C} \equiv\right.$ $\left.\mathrm{C}-\mathrm{C}(\mathrm{NR})_{2}\right]^{-}\left(\mathrm{R}=\mathrm{Cy},{ }^{\mathrm{i}} \mathrm{Pr}\right)$ represent a potentially useful addition to the current library of amidinate ligands. In a first contribution we described the synthesis and full characterization of the lithium-cyclopropylethinylamidinates $\mathrm{Li}\left[\mathrm{c}-\mathrm{C}_{3} \mathrm{H}_{5}-\mathrm{C} \equiv \mathrm{C}-\mathrm{C}(\mathrm{NR})_{2}\right]$ (1a: $\mathrm{R}=$ cyclohexyl $\left.(\mathrm{Cy}), \mathbf{1 b}: \mathrm{R}={ }^{\mathrm{i}} \mathrm{Pr}\right) .{ }^{10}$ These precursors are readily available on a large scale and in high yields using 
commercially available starting materials. In a subsequent study, their use as precursors for new lanthanide amidinates could be demonstrated by the synthesis of a series of new Ln(III) bis(cyclopropylethinylamidinates). In the case of Ce and $\mathrm{Nd}$, the chloro-bridged dimers $\left[\left\{\mathrm{c}-\mathrm{C}_{3} \mathrm{H}_{5}-\mathrm{C} \equiv \mathrm{C}-\mathrm{C}(\mathrm{NR})_{2}\right\}_{2} \mathrm{Ln}(\mu-\mathrm{Cl})(\mathrm{THF})\right]_{2}$ $\left(\mathrm{Ln}=\mathrm{Ce}, \mathrm{Nd} ; \mathrm{R}=\mathrm{Cy},{ }^{\mathrm{i}} \mathrm{Pr}\right)$ were isolated, whereas the smaller holmium afforded the "ate" complex $\left[\mathrm{c}-\mathrm{C}_{3} \mathrm{H}_{5}-\mathrm{C} \equiv \mathrm{C}-\mathrm{C}(\mathrm{NCy})_{2}\right]_{2}$ $\mathrm{Ho}(\mu-\mathrm{Cl})_{2} \mathrm{Li}(\mathrm{THF})\left(\mathrm{OEt}_{2}\right)$. An initial study showed that these complexes effectively catalyze the addition of aniline derivatives to carbodiimides to give $\mathrm{N}$-arylguanidines. ${ }^{11}$ Herein we report the synthesis and structural characterization of the first homoleptic Ln(III) tris(cyclopropylethinylamidinate) complexes as well as an initial study of their possible use as homogeneous catalysts for the addition of terminal alkynes to carbodiimides.

\section{Results and discussion}

\subsection{Synthesis and structure}

The starting materials used in this study, the lithium-cyclopropylethinylamidinates $\mathrm{Li}\left[\mathrm{c}-\mathrm{C}_{3} \mathrm{H}_{5}-\mathrm{C} \equiv \mathrm{C}-\mathrm{C}(\mathrm{NR})_{2}\right](\mathbf{1 a}: \mathrm{R}=\mathrm{Cy}$, 1b: $\mathrm{R}={ }^{\mathrm{i}} \mathrm{Pr}$ ), were prepared in a straightforward manner according to Scheme 1 by in situ-deprotonation of commercially available cyclopropylacetylene followed by treatment with either $N, N^{\prime}$-diisopropylcarbodiimide or $N, N^{\prime}$-dicyclohexylcarbodiimide according to the published procedure. These lithium amidinates can be isolated in the form of stable, crystalline solids as adducts with donor solvent like diethyl ether, THF or

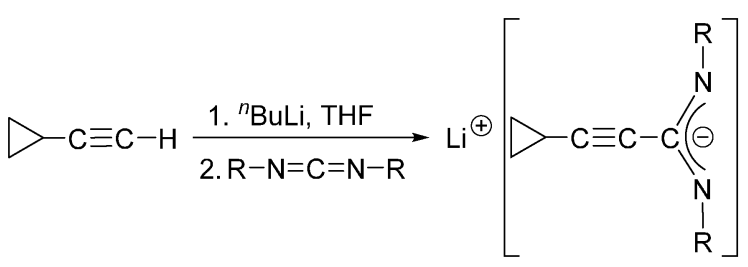

1a: $\mathrm{R}=c-\mathrm{C}_{6} \mathrm{H}_{11}(=\mathrm{Cy}) ; \mathbf{1 b}: \mathrm{R}={ }^{i} \mathrm{Pr}$

Scheme 1 Synthesis of the lithium-cyclopropylethinylamidinates $1 \mathbf{a}$ and $\mathbf{1 b}$.
DME (1,2-dimethoxyethane). ${ }^{10}$ However, for the reactions with lanthanide trichlorides, the reagents $\mathbf{1 a}$ and $\mathbf{1 b}$ were conveniently prepared in THF solution and used in situ.

Subsequent reactions of the lithium-cyclopropylethinylamidinates $\mathbf{1 a}$ and $\mathbf{1 b}$ with anhydrous lanthanide trichlorides, $\mathrm{LnCl}_{3}(\mathrm{Ln}=\mathrm{Nd}, \mathrm{Sm}, \mathrm{Ho})$ were carried out in a 1:3 molar ratio in THF solutions according to Scheme 2. Evaporation of the volatiles and recrystallization of the crude products from $n$-pentane afforded the new lanthanide(III) tris(cyclopropylethinylamidinate) complexes $2 \mathrm{a}-\mathbf{d}$ in moderate (2b: $54 \%, 2 \mathrm{c}: 45 \%, 2 \mathrm{~d}$ : $55 \%$ ) to good (2a: 79\%) yields. The samarium and holmium derivatives $2 \mathbf{a}, \mathbf{2 c}$, and 2d were isolated as yellow, air- and moisture-sensitive crystals, while the neodymium complex $\mathbf{2} \mathbf{b}$ is a green, crystalline solid. All four compounds are highly soluble in THF, diethyl ether, toluene and $n$-pentane. The very high solubility even in non-polar solvents like $n$-pentane certainly accounts for the relatively low yields in the case of complexes $\mathbf{2 b}$-d. A single-crystal X-ray diffraction study of the holmium derivative $2 \mathbf{d}$ (vide infra) confirmed the presence of the expected unsolvated, homoleptic lanthanide(III) tris(cyclopropylethinylamidinate) complex.

All four compounds were characterized by their NMR $\left({ }^{1} \mathrm{H},{ }^{13} \mathrm{C}\right)$ and IR spectra as well as elemental analyses. Despite the paramagnetic nature of the $\mathrm{Ln}^{3+}$ ions employed here, meaningful NMR spectra could be obtained for all four compounds with the exception of the ${ }^{1} \mathrm{H}$ NMR spectrum of the $\mathrm{Ho}^{3+}$ complex $2 \mathrm{c}$. The data were in good agreement with the formation of unsolvated lanthanide(III) tris(cyclopropylethinylamidinates). No signals attributable to coordinated THF could be observed. The IR spectra of 2a-c were found to be almost superimposable. IR bands resulting from the $\mathrm{C}=\mathrm{N}$ stretching vibrations of the $\mathrm{N}-\mathrm{C}-\mathrm{N}$ units appear at around $1606-1612 \mathrm{~cm}^{-1}$, whereas very strong bands at $2220-$ $2227 \mathrm{~cm}^{-1}$ can be assigned to the $\mathrm{C} \equiv \mathrm{C}$ vibrations. In all cases the EI mass spectra indicated good volatility of the new homoleptic lanthanide amidinates as they all showed the molecular ions in an intensity range of $20-45 \%$ relative intensity.

As a typical representative of the new homoleptic lanthanide tris(amidinates), the holmium derivative 2d was structurally authenticated through single-crystal X-ray diffraction (Fig. 1).

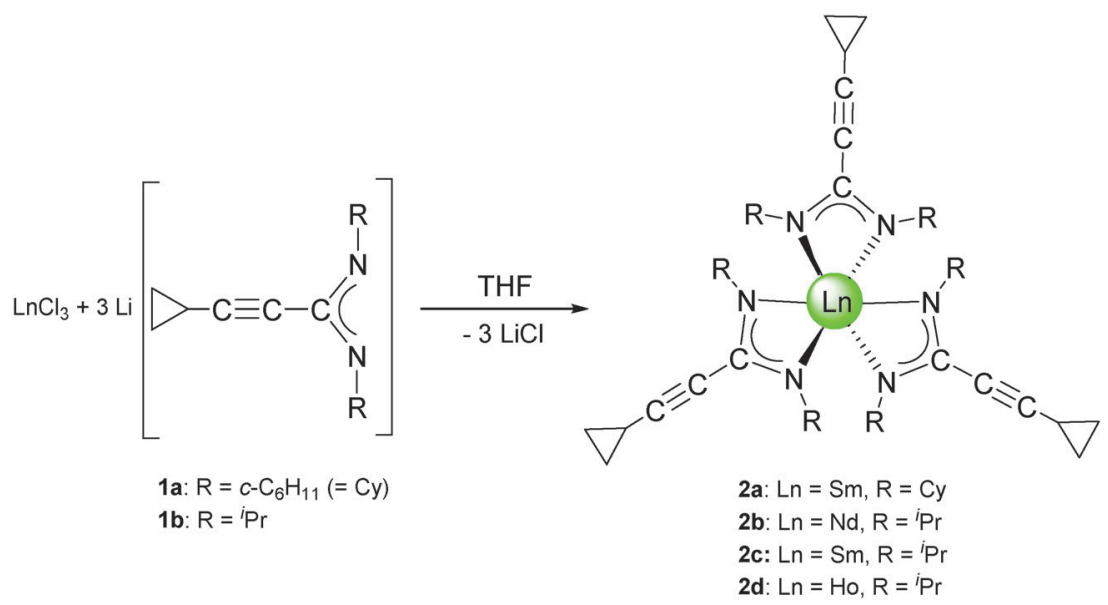

Scheme 2 Synthesis of the Ln(III) tris(cyclopropylethinylamidinates) 2 a-d. 


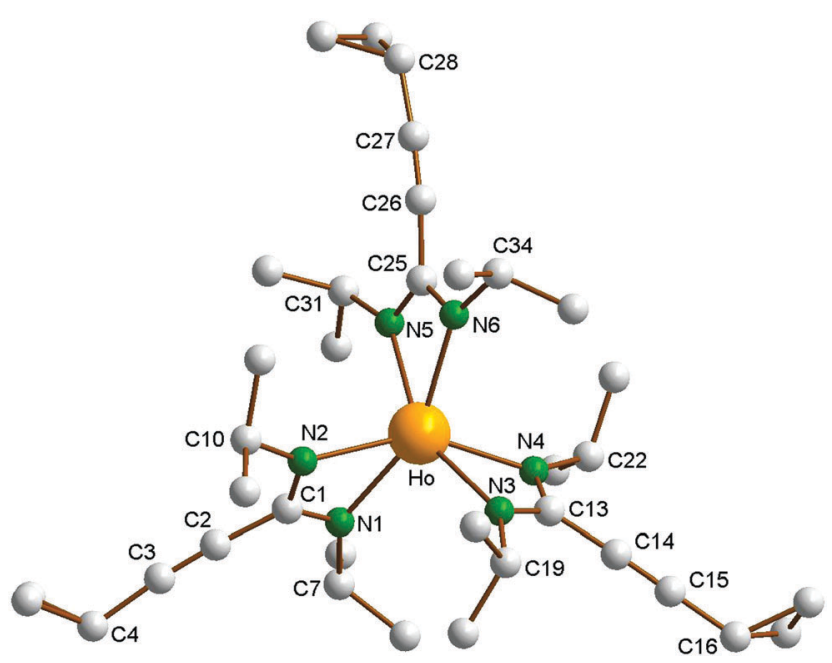

Fig. 1 Molecular structure of complex $\left[\mathrm{C}-\mathrm{C}_{3} \mathrm{H}_{5}-\mathrm{C} \equiv \mathrm{CC}\left(\mathrm{N}^{i} \mathrm{Pr}\right)_{2}\right]_{3} \mathrm{Ho}(\mathbf{2 d})$. All hydrogen atoms are omitted for clarity. Selected bond lengths ( $\AA$ ) and angles $\left(^{\circ}\right)$ : Ho-N1 2.359(3), Ho-N2 2.351(3), Ho-N3 2.348(2), HoN4 2.353(3), Ho-N5 2.342(2), Ho-N6 2.383(3), C1-N1 1.312(4), C1N2 1.327(4), C13-N3 1.333(4), C13-N4, 1.331(4), C25-N5 1.333(4), C25N6 1.324(3), C7-N1 1.481(4), C1-C2 1.461(5), C2-C3 1.182(6), C14C15 1.185(4), C26-C27 1.184(5), N1-Ho-N2 57.08(9), N3-Ho-N4 57.74(9), N5-Ho-N6 57.14(8), N1-Ho-N3 100.1(11), N2-Ho-N5 98.77(10), N4-Ho-N6 98.74(11), N1-C1-N2 117.0(3), N3-C13-N4 116.9(3), N5-C25-N6 116.6(3).

Pale yellow, block-like single-crystals of $\mathbf{2 d}$ were obtained by cooling of a very concentrated solution in $n$-pentane to $-30{ }^{\circ} \mathrm{C}$ over a prolonged period of time. Crystallographic data of $\mathbf{2 d}$ are listed in Table 1, while selected bond lengths and angles are summarized in the caption of Fig. 1. Compound $2 \mathbf{d}$ crystallizes in the triclinic space group $P \overline{1}$. The crystal structure determination clearly confirmed the presence of the first unsolvated homoleptic lanthanide(III) tris(cyclopropylethinylamidinate) complex. The central $\mathrm{Ho}^{3+}$ ion is coordinated by three chelating $\left[\mathrm{c}-\mathrm{C}_{3} \mathrm{H}_{5}-\mathrm{C} \equiv\right.$ $\left.\mathrm{C}-\mathrm{C}\left(\mathrm{N}^{\mathrm{i}} \mathrm{Pr}\right)_{2}\right]^{-}$ligands in a highly distorted octahedral fashion. To our knowledge, only three closely related homoleptic Ln(III) tris(phenylethinylamidinate) complexes of the type $[\mathrm{Ph}-\mathrm{C} \equiv$ $\left.\mathrm{C}-\mathrm{C}\left(\mathrm{N}^{\mathrm{i}} \mathrm{Pr}\right)_{2}\right]_{3} \mathrm{Ln}\left(\mathrm{Ln}=\mathrm{Y},{ }^{8 b} \mathrm{Ce},{ }^{8 a} \mathrm{Lu}^{8 b}\right)$ have been reported in the previous literature. All three complexes have also been structurally characterized by X-ray diffraction. The overall structural features of $\mathbf{2 d}$ are very similar to those reported for $[\mathrm{Ph}-\mathrm{C} \equiv$ $\left.\mathrm{C}-\mathrm{C}\left(\mathrm{N}^{\mathrm{i}} \mathrm{Pr}\right)_{2}\right]_{3} \mathrm{Ln}(\mathrm{Ln}=\mathrm{Y}, \mathrm{Ce}, \mathrm{Lu})$. The Ho-N distances in $\mathbf{2 d}$ are in the very narrow range of $2.342(2)-2.383(3) \AA$. As a result of the lanthanide contraction, ${ }^{12}$ these values are virtually identical with those reported for the yttrium(III)-tris(phenylethinylamidinate) complex $\left[\mathrm{Ph}-\mathrm{C} \equiv \mathrm{C}-\mathrm{C}\left(\mathrm{N}^{\mathrm{i}} \mathrm{Pr}\right)_{2}\right]_{3} \mathrm{Y}(\mathrm{Y}-\mathrm{N} 2.363(4)$ and 2.356(4) $\AA$ ). The average $\mathrm{N}-\mathrm{Ho}-\mathrm{N}$ bite angle to the chelating amidinate ligands in $\mathbf{2 d}$ is $57.33(9)^{\circ}$. This is also favorably comparable to the corresponding $\mathrm{N}-\mathrm{Ln}-\mathrm{N}$ angles found in the three phenylethinylamidinates $\left[\mathrm{Ph}-\mathrm{C} \equiv \mathrm{C}-\mathrm{C}\left(\mathrm{N}^{\mathrm{i}} \mathrm{Pr}\right)_{2}\right]_{3} \mathrm{Ln}(\mathrm{Ln}=\mathrm{Y}, \mathrm{Ce}, \mathrm{Lu})$ and in other homoleptic lanthanide tris( $N, N^{\prime}$-dialkylamidinates $) .{ }^{1,8}$ The bond lengths of the triple bonds in the cyclopropylethinyl units in 2d are 1.182(6) $\AA$ (C2-C3), 1.185(4) $\AA$ (C14-C15) and 1.184(5) ̊̊ (C22-C23).

\subsection{Catalytic activity}

For a first study of the possible catalytic activity of the new Ln(III) tris(cyclopropylethinylamidinate) we chose the catalytic addition of alkynes to carbodiimides to give substituted propiolamidines. The lanthanide-catalyzed synthesis of propiolamidines $\mathrm{R}-\mathrm{C} \equiv$ $\mathrm{C}-\mathrm{C}\left(=\mathrm{NR}^{\prime}\right)\left(\mathrm{NHR}^{\prime}\right)$ was first reported in 2005 by Hou et al. using rare-earth metal half-sandwich complexes as catalysts.

Table 1 Crystallographic data and structure refinement parameters for compounds $\mathbf{2 d}$ and $\mathbf{4}$

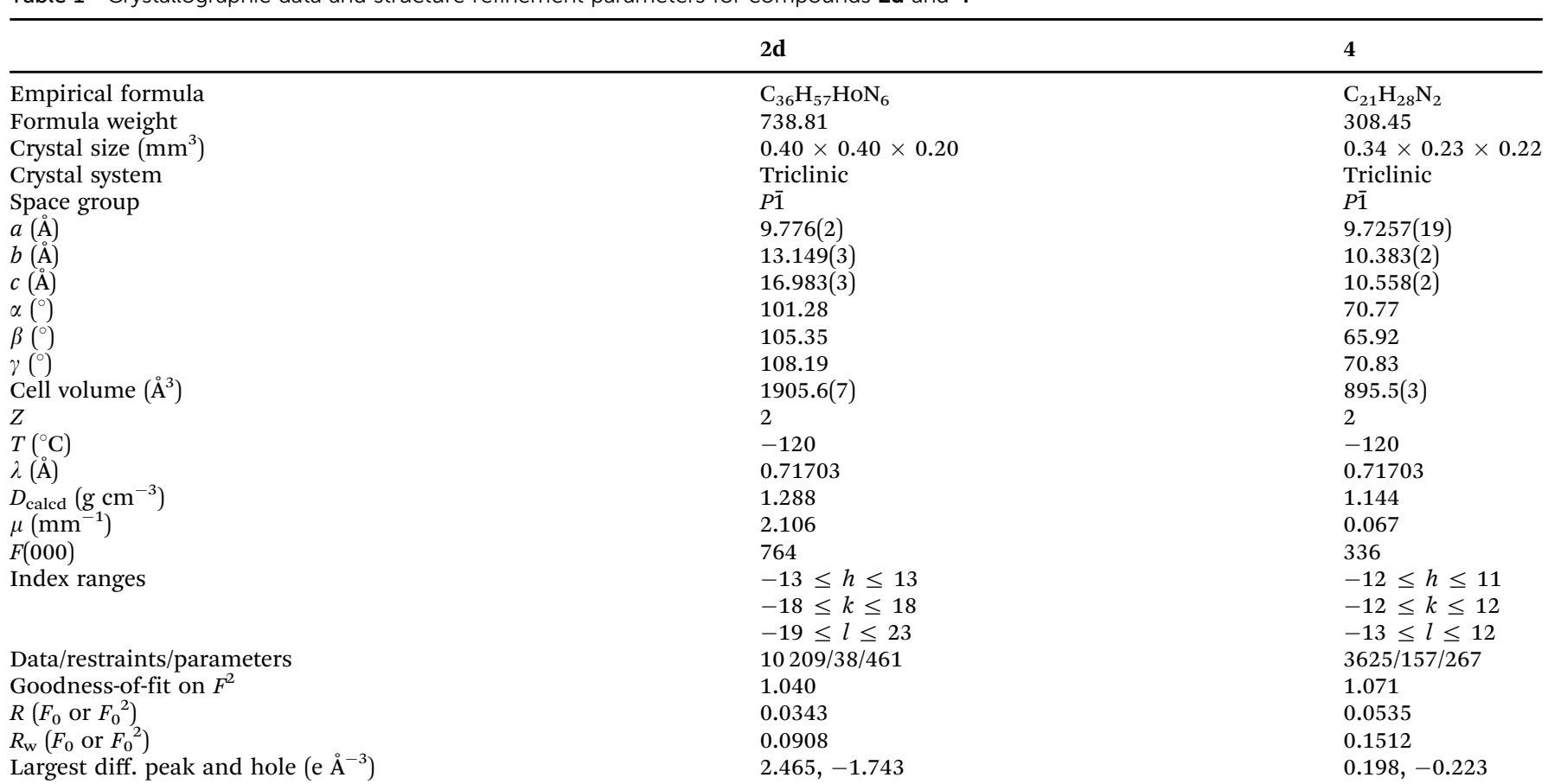




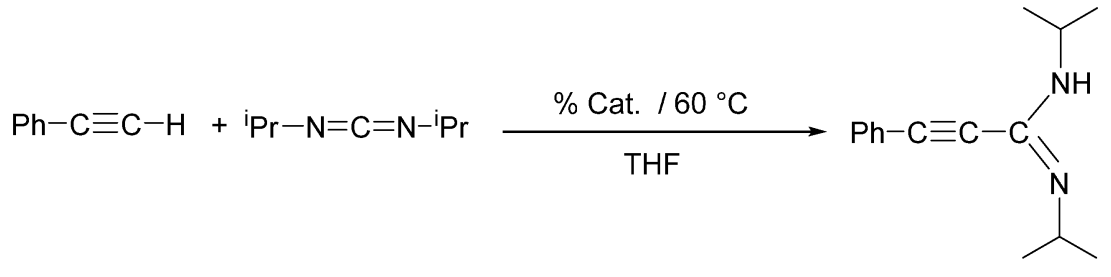

Scheme 3 Synthesis of $\mathrm{Ph}-\mathrm{C} \equiv \mathrm{C}-\mathrm{C}\left(\mathrm{N}^{i} \mathrm{Pr}\right)\left(\mathrm{NH}^{i} \mathrm{Pr}\right)(\mathbf{3})$ using $\mathbf{2 a}-\mathbf{d}$ as catalyst.

Table 2 Addition of phenylacetylene to $N, N^{\prime}$-diisopropylcarbodiimide catalyzed by the lanthanide-tris(cyclopropylethinylamidinates) $\mathbf{2 a - d}$

\begin{tabular}{lllll}
\hline Entry $^{a}$ & Cat. & Catalyst equiv. (mol\%) & Time (h) & Yield $^{b}$ of $3(\%)$ \\
\hline 1 & 2a & 0.5 & 1 & 72 \\
2 & 2a & 1 & 0.5 & 85 \\
3 & 2b & 0.5 & 1 & 53 \\
4 & 2b & 1 & 0.5 & 62 \\
5 & 2c & 0.5 & 1 & 54 \\
6 & 2c & 1 & 0.5 & 51 \\
7 & 2d & 0.5 & 1 & 34 \\
8 & 2d & 1 & 0.5 & 27 \\
11 & None & 0 & 1 & 0 \\
\multicolumn{5}{l}{ General condition: THF as solvent at $60{ }^{\circ}$ C. ${ }^{b}$ Isolated yield. }
\end{tabular}

The pre-catalysts used in this study were constrained-geometry-type complexes such as $\left[\mathrm{Me}_{2} \mathrm{Si}\left(\mathrm{C}_{5} \mathrm{Me}_{4}\right)(\mathrm{NPh})\right] \mathrm{Y}\left(\mathrm{CH}_{2} \mathrm{SiMe}_{3}\right)(\mathrm{THF})_{2}$. It was found that half-sandwich complexes comprising a propiolamidinate ligand play an important role in the catalytic cycle. Upon treatment with excess acetylene, they release the propiolamidine product. $^{7 a}$ Most recently, Zhang and Zhou et al. employed rare-earth metal alkyl complexes stabilized by the bulky pyrazolylborate ligand $\mathrm{Tp}^{\mathrm{Me} 2}$ (=hydro-tris(3,5-dimethylpyrazolyl)-borate) as catalysts for the synthesis of $\mathrm{N}$-aryl-substituted propiolamidines. ${ }^{7 g}$

In an initial screening test, we examined the Ln-catalyzed addition of phenylacetylene to $N, N^{\prime}$-diisopropylcarbodiimide in the

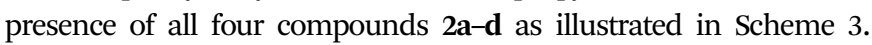
All four new lanthanide(III)-tris(cyclopropylethinylamidinates) 2a-d were used as precatalysts, and the reactions were carried out in concentrated THF solutions at $60{ }^{\circ} \mathrm{C}$. The results are summarized in Table 2. The isolated yields of the known compound $\mathrm{Ph}-\mathrm{C} \equiv$ $\mathrm{C}-\mathrm{C}\left(\mathrm{N}^{\mathrm{i}} \mathrm{Pr}\right)\left(\mathrm{NH}^{\mathrm{i}} \mathrm{Pr}\right)(3)^{13}$ varied from 27 to $85 \%$ depending of the lanthanide metal employed. Clearly the highest activity was observed for the samarium complex $\left[\mathrm{c}-\mathrm{C}_{3} \mathrm{H}_{5}-\mathrm{C} \equiv \mathrm{C}-\mathrm{C}(\mathrm{NCy})_{2}\right]_{3} \mathrm{Sm}$ (2a), while the lowest yields were obtained when using the holmium catalyst $\left[\mathrm{c}-\mathrm{C}_{3} \mathrm{H}_{5}-\mathrm{C} \equiv \mathrm{C}-\mathrm{C}\left(\mathrm{N}^{\mathrm{i}} \mathrm{Pr}\right)_{2}\right]_{3} \mathrm{Ho}$ (2d). In a control experiment
(Table 2, entry 11), an equimolar mixture of phenylacetylene and $N, N^{\prime}$-diisopropylcarbodiimide were heated in concentrated THF solution at $60{ }^{\circ} \mathrm{C}$ for $1 \mathrm{~h}$ in the absence of a rare-earth metal compound. Under these conditions, no trace of $\mathrm{Ph}-\mathrm{C} \equiv$ $\mathrm{C}-\mathrm{C}\left(\mathrm{N}^{\mathrm{i}} \mathrm{Pr}\right)\left(\mathrm{NH}^{\mathrm{i}} \mathrm{Pr}\right)(3)$ could be detected in the reaction mixture.

In a second set of experiments, the Ln-catalyzed addition of three different terminal alkynes to both $N, N^{\prime}$-diisopropylcarbodiimide and $N, N^{\prime}$-dicyclohexylcarbodiimide was studied. For these tests, the most

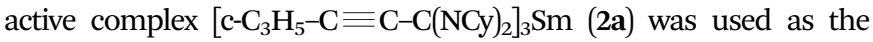
precatalyst. The reactions were again carried out in THF at $60{ }^{\circ} \mathrm{C}$ according to Scheme 4 .

As can be seen from the results listed in Table 3, this short screening produced mixed results. Reactions of phenylacetylene with both $N, N^{\prime}$-diisopropylcarbodiimide and $N, N^{\prime}$-dicyclohexylcarbodiimide gave good yields of the hydroacetylenation products 3 and 4, while cyclopropylacetylene could be added only to $N, N^{\prime}$-dicyclohexylcarbodiimide affording a moderate yield of propiolamidine 5. In sharp contrast, virtually no reactions were observed when trimethylsilylacetylene was employed. Thus the use of the new homoleptic lanthanide(III)-tris(cyclopropylethinylamidinates) as catalysts for the addition of terminal acetylenes to carbodiimides appears to be quite limited. Obviously these amidinate complexes cannot seriously compete with previously reported rare-earth metal catalysts comprising cyclopentadienyl ${ }^{7 a}$ or pyrazolylborate ${ }^{7 g}$ ligands. These compounds all contain additional $\sigma$-alkyl groups such as $-\mathrm{CH}_{2} \mathrm{Ph}$ or $-\mathrm{CH}_{2} \mathrm{SiMe}_{3}$ which certainly account for the significantly higher activity of such catalysts systems. ${ }^{7 a, g}$

In the course of the present study, the molecular structure of the propiolamidine $\mathbf{4}$ has been verified by single-crystal X-ray diffraction ( $c f$. Table 1). X-Ray-quality single-crystals of 4 were grown by slowly cooling a solution in hot acetonitrile to room temperature. The molecular structure of $\mathbf{4}$ is shown in Fig. 2. Previously reported crystal structures of propiolamidines include

$$
\mathrm{R}-\mathrm{C} \equiv \mathrm{C}-\mathrm{H}+\mathrm{R}_{1}-\mathrm{N}=\mathrm{C}=\mathrm{N}-\mathrm{R}_{1} \stackrel{\% 2 \mathrm{a} / 60^{\circ} \mathrm{C}}{\mathrm{THF}}
$$

Scheme 4 Synthesis of alkynylamidines using complex $2 \mathrm{a}$ as catalyst. 
Table 3 Catalytic addition of terminal alkynes to $N, N^{\prime}$-diisopropylcarbodiimide catalyzed by $\mathbf{2 a}$

\begin{tabular}{llllll}
\hline Entry ${ }^{a, b}$ & $\mathrm{R}$ & $\mathrm{R}_{1}$ & Time $(\mathrm{h})$ & Product & Yield $^{c}(\%)$ \\
\hline 1 & $\mathrm{Ph}$ & ${ }^{\mathrm{i}} \mathrm{Pr}$ & 0.5 & $\mathbf{3}$ & 85 \\
2 & $\mathrm{Ph}$ & $\mathrm{Cy}$ & 0.5 & $\mathbf{4}$ & 78 \\
3 & $\mathrm{c}^{\mathrm{C}} \mathrm{C}_{3} \mathrm{H}_{5}$ & ${ }^{\mathrm{i}} \mathrm{Pr}$ & 0.5 & - & Traces \\
4 & $\mathrm{c}^{-}{ }_{3} \mathrm{H}_{5}$ & $\mathrm{Cy}$ & 1 & $\mathbf{5}$ & 48 \\
5 & $\mathrm{Me}_{3} \mathrm{Si}$ & ${ }^{\mathrm{i}} \mathrm{Pr}$ & 0.5 & - & Traces \\
6 & $\mathrm{Me}_{3} \mathrm{Si}$ & $\mathrm{Cy}$ & 1 & - & Traces
\end{tabular}

${ }^{a}$ General condition: THF as solvent at $60{ }^{\circ} \mathrm{C} .{ }^{b}$ All reactions carried out using $1.0 \% \mathrm{~mol}$ of $2 \mathrm{a} .{ }^{c}$ Isolated yield.

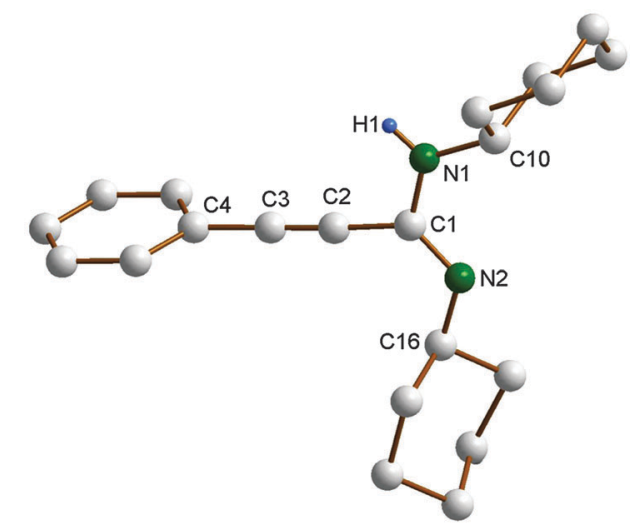

Fig. 2 Molecular structure of complex of $\mathrm{C}_{6} \mathrm{H}_{5}-\mathrm{C} \equiv \mathrm{C}-\mathrm{C}(\mathrm{NCy})(\mathrm{NHCy})$ (4). Most of the hydrogen atoms are omitted for clarity. Selected bond lengths $(\AA \AA)$ and angles $\left(^{\circ}\right)$ : C1-N1 1.364(2), C1-N2 1.275(2), C1-C2 1.451(2), C2-C3 1.195(3), C10-N1 1.451(3), N1-C1-N2 121.93(17), C10-N1-C1 125.79(15), C16-N2-C1 117.4(4).

those of $4-\mathrm{ClC}_{6} \mathrm{H}_{4}-\mathrm{C} \equiv \mathrm{C}-\mathrm{C}\left(\mathrm{N}^{\mathrm{i}} \mathrm{Pr}\right)\left(\mathrm{NH}^{\mathrm{i}} \mathrm{Pr}\right)$ and $2-\mathrm{ClC}_{6} \mathrm{H}_{4}-\mathrm{C} \equiv$ $\mathrm{C}-\mathrm{C}\left(\mathrm{N}^{\mathrm{i}} \mathrm{Pr}\right)\left(\mathrm{NH}^{\mathrm{i}} \mathrm{Pr}\right){ }^{7 a} \mathrm{Ph}-\mathrm{C} \equiv \mathrm{C}-\mathrm{C}\left(\mathrm{NC}_{6} \mathrm{H}_{3}{ }^{\mathrm{i}} \mathrm{Pr}_{2}-2,6\right)\left(\mathrm{NHC}_{6} \mathrm{H}_{3}{ }^{\mathrm{i}} \mathrm{Pr}_{2}-2,6\right),{ }^{14}$ and $\mathrm{Ph}-\mathrm{C} \equiv \mathrm{C}-\mathrm{C}\left(\mathrm{NC}_{6} \mathrm{H}_{3}{ }^{\mathrm{i}} \mathrm{Pr}_{2}-2,6\right)\left(\mathrm{NHC}_{6} \mathrm{H}_{3} \mathrm{Cl}_{2}-3,4\right) .{ }^{7 g}$ The $\mathrm{C} \equiv \mathrm{C}$ bond length in 4 is 1.195(3) $\AA$, while the C1-N1 and C1-N2 distance (1.364(2) and 1.275(4) $\AA$ ) correspond to standard $\mathrm{C}-\mathrm{N}$ single and double bonds, respectively. As in $4-\mathrm{ClC}_{6} \mathrm{H}_{4}-\mathrm{C} \equiv \mathrm{C}-\mathrm{C}\left(\mathrm{N}^{\mathrm{i}} \mathrm{Pr}\right)\left(\mathrm{NH}^{\mathrm{i}} \mathrm{Pr}\right)$ and $2-\mathrm{ClC}_{6} \mathrm{H}_{4}-\mathrm{C} \equiv \mathrm{C}-\mathrm{C}\left(\mathrm{N}^{\mathrm{i}} \mathrm{Pr}\right)\left(\mathrm{NH}^{\mathrm{i}} \mathrm{Pr}\right){ }^{7 a}$ one cyclohexyl substituent points toward the alkynyl group and the other one away, resulting in a transoid conformation around the $\mathrm{N}-\mathrm{C}-\mathrm{N}$ unit. In contrast, a cisoid conformation (both substituents pointing toward the alkynyl group) has been reported for $\mathrm{Ph}-\mathrm{C} \equiv \mathrm{C}-\mathrm{C}\left(\mathrm{NC}_{6} \mathrm{H}_{3}{ }^{\mathrm{i}} \mathrm{Pr}_{2}-\right.$ $2,6)\left(\mathrm{NHC}_{6} \mathrm{H}_{3}{ }^{\mathrm{i}} \mathrm{Pr}_{2}-2,6\right)^{14}$ and $\mathrm{Ph}-\mathrm{C} \equiv \mathrm{C}-\mathrm{C}\left(\mathrm{NC}_{6} \mathrm{H}_{3}{ }^{\mathrm{i}} \mathrm{Pr}_{2}-2,6\right)\left(\mathrm{NHC}_{6} \mathrm{H}_{3} \mathrm{Cl}_{2}-\right.$ $3,4)^{7 g}$ which both contain bulky 2,6-diisopropylphenyl substituents.

\section{Conclusions}

In summarizing the work reported here, we succeeded in the straightforward preparation of a series of new homoleptic lanthanide tris(cyclopropylethinylamidinate) complexes comprising neodymium, samarium, and holmium as central metals. The lithium-cyclopropylethinylamidinate precursors employed in these preparations are readily available in one step from commercially available starting materials. The new complexes 2a-d are highly soluble even in non-polar solvents such as $n$-pentane. The presence of unsolvated, homoleptic tris(cyclopropylethinylamidinate) complexes could be verified by an X-ray crystal structure determination of the holmium complex 2d. An initial catalysis study revealed that the new amidinates effectively catalyze the addition of phenylacetylene to $N, N^{\prime}$-diisopropylcarbodiimide and $N, N^{\prime}$-dicyclohexylcarbodiimide but have insufficient activity with other terminal acetylenes.

\section{Experimental section}

\subsection{General procedures}

All experiments were carried out in oven-dried or flame-dried glassware under an inert atmosphere of dry argon employing standard Schlenk and glovebox techniques $\left(<1 \mathrm{ppm} \mathrm{O}_{2},<1 \mathrm{ppm}\right.$ $\mathrm{H}_{2} \mathrm{O}$ ). $n$-Pentane and THF were distilled from sodium/benzophenone under nitrogen atmosphere prior to use. All glassware was oven-dried at $120{ }^{\circ} \mathrm{C}$ for at least $24 \mathrm{~h}$, assembled while hot, and cooled under high vacuum prior to use. The starting materials, anhydrous $\mathrm{LnCl}_{3}(\mathrm{Ln}=\mathrm{Ce}, \mathrm{Nd}),{ }^{15}$ and the lithiumcyclopropylethinyl-amidinate precursors $\mathbf{1 a}$ and $\mathbf{1} \mathbf{b}^{\mathbf{1 0}}$ were prepared according to the literature methods. ${ }^{1} \mathrm{H}-\mathrm{NMR}(400 \mathrm{MHz})$ and ${ }^{13} \mathrm{C}-\mathrm{NMR}(100.6 \mathrm{MHz})$ were recorded in $\mathrm{C}_{6} \mathrm{D}_{6}$ or $\mathrm{CDCl}_{3}$ solutions on a Bruker DPX 400 spectrometer at $25{ }^{\circ} \mathrm{C}$. Chemical shifts were referenced to TMS. Assignment of signals was made from ${ }^{1} \mathrm{H}-{ }^{13} \mathrm{C}$ HSQC $2 \mathrm{D}$ NMR experiments. IR spectra were recorded using $\mathrm{KBr}$ pellets on a Perkin Elmer FT-IR spectrometer system 2000 between $4000 \mathrm{~cm}^{-1}$ and $400 \mathrm{~cm}^{-1}$. Microanalyses of the compounds were performed using a Leco CHNS 923 apparatus.

\subsection{Synthesis and characterization of the $\operatorname{Ln}(\mathrm{III})-$ tris(cyclopropylethinylamidinates) 2a-d}

$\left[\mathbf{c}-\mathrm{C}_{3} \mathrm{H}_{5}-\mathrm{C} \equiv \mathbf{C C}(\mathrm{NCy})_{2}\right]_{3} \mathrm{Sm}$ (2a). Anhydrous $\mathrm{SmCl}_{3}(1.0 \mathrm{~g}$, $4 \mathrm{mmol})$ and $\mathbf{1 b}(3.3 \mathrm{~g}, 12 \mathrm{mmol})$ were charged in a $250 \mathrm{ml}$ Schlenk flask. $100 \mathrm{ml}$ of THF were added and the mixture was stirred $12 \mathrm{~h}$ at r.t. to give a clear yellow solution. The solvent was removed under vacuum followed by extraction with $n$-pentane $(2 \times 15 \mathrm{ml})$. The clear yellow flitrate was evaporated under vacuum affording $\mathbf{2 a}$ as a pale yellow solid (3.0 g, 79\%). ${ }^{1} \mathrm{H}$ NMR (400 MHz, $\left.\mathrm{C}_{6} \mathrm{D}_{6}, 25{ }^{\circ} \mathrm{C}\right): \delta=3.34$ (m, 6H, CH, Cy), $1.85\left(\mathrm{~m}, 3 \mathrm{H}, \mathrm{CH}, \mathrm{c}^{-} \mathrm{C}_{3} \mathrm{H}_{5}\right), 1.56$ (br, $\left.12 \mathrm{H}, \mathrm{CH}_{2}, \mathrm{Cy}\right), 1.40(\mathrm{~m}, 6 \mathrm{H}$, $\mathrm{CH}_{2}, \mathrm{c}-\mathrm{C}_{3} \mathrm{H}_{5}$ ), 0.97-1.32 (m, 18H, $\left.\mathrm{CH}_{2}, \mathrm{Cy}\right), 0.87\left(\mathrm{~m}, 6 \mathrm{H}, \mathrm{CH}_{2}\right.$, c- $\mathrm{C}_{3} \mathrm{H}_{5}$ ), 0.69 (br, $12 \mathrm{H}, \mathrm{CH}_{2}, \mathrm{Cy}$ ), -0.21 to -0.12 (q, $6 \mathrm{H}, \mathrm{CH}_{2}, \mathrm{Cy}$ ), -2.31 (br, $\left.12 \mathrm{H}, \mathrm{CH}_{2}, \mathrm{Cy}\right) ;{ }^{13} \mathrm{C}\left\{{ }^{1} \mathrm{H}\right\}$ NMR $\left(100.6 \mathrm{MHz}, \mathrm{C}_{6} \mathrm{D}_{6}, 25{ }^{\circ} \mathrm{C}\right)$ : $\delta=201.9(\mathrm{NCN}), 104.1(\mathrm{C} \equiv \mathrm{C}-\mathrm{C}), 73.7(\mathrm{HC}-\mathrm{C} \equiv \mathrm{C}), 56.9(\mathrm{CH}$, Cy), $35.8\left(\mathrm{CH}_{2}, \mathrm{Cy}\right), 25.5\left(\mathrm{CH}_{2}, \mathrm{Cy}\right), 9.8\left(\mathrm{CH}_{2}, \mathrm{c}-\mathrm{C}_{3} \mathrm{H}_{5}\right), 1.8(\mathrm{CH}$, c- $\mathrm{C}_{3} \mathrm{H}_{5}$ ). MS (EI, $\left.M=965.57\right): \mathrm{m} / z$ (\%) 965.7(45) [M], 695.4(70) $\left[\mathrm{M}-\left(\mathrm{c}-\mathrm{C}_{3} \mathrm{H}_{5}-\mathrm{C} \equiv \mathrm{CC}(\mathrm{NCy})_{2}\right)\right]^{+}, 272.2(80)\left[\mathrm{c}-\mathrm{C}_{3} \mathrm{H}_{5}-\mathrm{C} \equiv \mathrm{CC}(\mathrm{NCy})_{2}\right]^{+}$, 229.1(58) $\left[\mathrm{c}-\mathrm{C}_{3} \mathrm{H}_{5}-\mathrm{C} \equiv \mathrm{CC}(\mathrm{NCy})_{2}-\left(\mathrm{c}-\mathrm{C}_{3} \mathrm{H}_{5}\right)\right]^{+}, 190.1(63)\left[\mathrm{c}-\mathrm{C}_{3} \mathrm{H}_{5}-\right.$ $\left.\mathrm{C} \equiv \mathrm{CC}(\mathrm{NCy})_{2}-(\mathrm{Cy})+2 \mathrm{H}\right]^{+}, 177(100)\left[\mathrm{c}-\mathrm{C}_{3} \mathrm{H}_{5}-\mathrm{C} \equiv \mathrm{CC}-\mathrm{NCy}+\right.$ $2 \mathrm{H}]^{+}$. IR (KBr): 3668, 3438, 3220, 3012, 2925, 2850, 2665, 2222, 1606, 1469, 1398, 1361, 1174, 1120, 1028, 972, 888, 703, 676, $588 \mathrm{~cm}^{-1}$. Anal. calcd for $\mathrm{C}_{54} \mathrm{H}_{81} \mathrm{~N}_{6} \mathrm{Sm}: \mathrm{C}, 67.24 ; \mathrm{H}, 8.46 ; \mathrm{N}$, 8.71\%. Found: C, 67.22; H, 8.51; N, 8.60\%.

$\left[\mathbf{c}-\mathrm{C}_{3} \mathrm{H}_{5}-\mathrm{C} \equiv \mathbf{C C}\left(\mathbf{N}^{\mathrm{i}} \mathbf{P r}\right)_{2}\right]_{3} \mathbf{N d}(2 \mathrm{~b})$. A solution of anhydrous $\mathrm{NdCl}_{3}(1.0 \mathrm{~g}, 4 \mathrm{mmol})$ in $30 \mathrm{ml}$ of $\mathrm{THF}$ was added to a solution 
of $1 \mathrm{a}(2.3 \mathrm{~g}, 12 \mathrm{mmol})$ in $70 \mathrm{ml}$ of THF. The reaction mixture was heated to $65{ }^{\circ} \mathrm{C}$ for $2 \mathrm{~h}$ and then stirred at r.t. for $12 \mathrm{~h}$. The solution color changed to blue. Work-up using n-pentane as described for 2a afforded $\mathbf{2 b}$ as green crystals (1.5 g, 54\%). ${ }^{1} \mathrm{H}$ NMR (400 MHz, $\left.\mathrm{C}_{6} \mathrm{D}_{6}, 25{ }^{\circ} \mathrm{C}\right): \delta=22.3\left(\mathrm{~m}, 6 \mathrm{H}, \mathrm{CH}-\left(\mathrm{CH}_{3}\right)_{2}\right)$, $4.10\left(\mathrm{~m}, 3 \mathrm{H}, \mathrm{CH}, \mathrm{c}-\mathrm{C}_{3} \mathrm{H}_{5}\right), 2.97\left(\mathrm{~m}, 6 \mathrm{H}, \mathrm{CH}_{2}, \mathrm{c}-\mathrm{C}_{3} \mathrm{H}_{5}\right), 2.02$ $\left(\mathrm{m}, 6 \mathrm{H}, \mathrm{CH}_{2}, \mathrm{c}-\mathrm{C}_{3} \mathrm{H}_{5}\right),-3.55\left(\mathrm{~m}, 36 \mathrm{H}, \mathrm{CH}_{3}\right) ;{ }^{13} \mathrm{C}\left\{{ }^{1} \mathrm{H}\right\}$ NMR (100.6 MHz, $\left.\mathrm{C}_{6} \mathrm{D}_{6}, 25{ }^{\circ} \mathrm{C}\right): \delta=228.6(\mathrm{NCN}), 108.5(\mathrm{C} \equiv \mathrm{C}-\mathrm{C})$, $65.3\left(\mathrm{CH}-\left(\mathrm{CH}_{3}\right)_{2}\right), 59.8(\mathrm{HC}-\mathrm{C} \equiv \mathrm{C}), 23.1\left(\mathrm{CH}_{3}\right), 12.1\left(\mathrm{CH}_{2}\right.$, c- $\left.\mathrm{C}_{3} \mathrm{H}_{5}\right), 2.4\left(\mathrm{CH}, \quad \mathrm{c}-\mathrm{C}_{3} \mathrm{H}_{5}\right) . \quad \mathrm{MS}(\mathrm{EI}, \quad M=715.37): \mathrm{m} / \mathrm{z}(\%)$ 631.6(33) $\left[\mathrm{M}-2\left({ }^{\mathrm{i}} \mathrm{Pr}\right)\right]^{+}, 396.4(20)\left[2\left(\mathrm{c}^{-} \mathrm{C}_{3} \mathrm{H}_{5}-\mathrm{C} \equiv \mathrm{CC}\left(\mathrm{N}^{\mathrm{i}} \mathrm{Pr}\right)_{2}\right)+\mathrm{CH}_{3}\right]^{+}$, $381.3(15) \quad\left[2\left(\mathrm{c}-\mathrm{C}_{3} \mathrm{H}_{5}-\mathrm{C} \equiv \mathrm{CC}\left(\mathrm{N}^{\mathrm{i}} \mathrm{Pr}\right)_{2}\right)\right]^{+}, \quad 205.2(50) \quad\left[\left(\mathrm{c}-\mathrm{C}_{3} \mathrm{H}_{5}-\right.\right.$ $\left.\left.\mathrm{C} \equiv \mathrm{CC}\left(\mathrm{N}^{\mathrm{i}} \mathrm{Pr}\right)_{2}\right)+\mathrm{CH}_{3}\right]^{+}, \quad 177.1(34) \quad\left[\mathrm{c}-\mathrm{C}_{3} \mathrm{H}_{5}-\mathrm{C} \equiv \mathrm{CC}\left(\mathrm{N}^{\mathrm{i}} \mathrm{Pr}\right)_{2}-\right.$ $\left.\mathrm{CH}_{3}\right]^{+}, 149.1(17)\left[\mathrm{c}-\mathrm{C}_{3} \mathrm{H}_{5}-\mathrm{C} \equiv \mathrm{CC}\left(\mathrm{N}^{\mathrm{i}} \mathrm{Pr}\right)_{2}-\left(\mathrm{c}-\mathrm{C}_{3} \mathrm{H}_{5}\right)\right]^{+}$. IR (KBr): 3678, 3439, 3220, 3015, 2963, 2867, 2608, 2220, 1865, 1635, 1591, 1498, 1382, 1332, 1169, 811, 716, 692, 530, $445 \mathrm{~cm}^{-1}$. Anal. calcd for $\mathrm{C}_{36} \mathrm{H}_{57} \mathrm{~N}_{6} \mathrm{Nd}$ : C, 60.16; H, 7.93; N, $11.69 \%$. Found: C, 60.25; H, 7.92; N, 11.52\%.

$\left[\mathrm{c}-\mathrm{C}_{3} \mathrm{H}_{5}-\mathrm{C} \equiv \mathbf{C C}\left(\mathrm{N}^{\mathrm{i}} \mathrm{Pr}\right)_{2}\right]_{3} \mathrm{Sm}$ (2c). A reaction of anhydrous $\mathrm{SmCl}_{3}(1.0 \mathrm{~g}, 4 \mathrm{mmol})$ with $1 \mathrm{a}(2.3 \mathrm{~g}, 12 \mathrm{mmol})$ following the procedure described for $\mathbf{2 a}$ afforded $\mathbf{2 d}$ as a yellow, crystalline solid (1.6 g, 55\%). ${ }^{1} \mathrm{H}$ NMR (400 MHz, $\left.\mathrm{C}_{6} \mathrm{D}_{6}, 25{ }^{\circ} \mathrm{C}\right): \delta=3.60$ $\left(\mathrm{m}, 6 \mathrm{H}, \mathrm{CH}-\left(\mathrm{CH}_{3}\right)_{2}\right), 1.81\left(\mathrm{~m}, 3 \mathrm{H}, \mathrm{CH}, \mathrm{c}-\mathrm{C}_{3} \mathrm{H}_{5}\right), 1.37(\mathrm{~m}, 6 \mathrm{H}$, $\left.\mathrm{CH}_{2}, \mathrm{c}-\mathrm{C}_{3} \mathrm{H}_{5}\right), 0.89\left(\mathrm{~m}, 6 \mathrm{H}, \mathrm{CH}_{2}, \mathrm{c}-\mathrm{C}_{3} \mathrm{H}_{5}\right),-0.47\left(\mathrm{~m}, 36 \mathrm{H}, \mathrm{CH}_{3}\right)$; ${ }^{13} \mathrm{C}\left\{{ }^{1} \mathrm{H}\right\}$ NMR $\left(100.6 \mathrm{MHz}, \mathrm{C}_{6} \mathrm{D}_{6}, 25{ }^{\circ} \mathrm{C}\right): \delta=201.6(\mathrm{NCN}), 104.5$ $(\mathrm{C} \equiv \mathrm{C}-\mathrm{C}), 73.5(\mathrm{HC}-\mathrm{C} \equiv \mathrm{C}), 48.3\left(\mathrm{CH}-\left(\mathrm{CH}_{3}\right)_{2}\right), 25.1\left(\mathrm{CH}_{3}\right), 9.7$

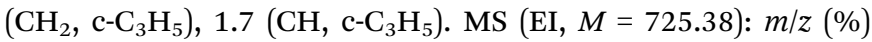
726.4(20) $[\mathrm{M}]^{+}, \quad 710.5(23)\left[\mathrm{M}-\mathrm{CH}_{3}\right]^{+}, \quad 533.3(10) \quad\left[\mathrm{M}-\mathrm{c}-\mathrm{C}_{3} \mathrm{H}_{5}-\right.$ $\left.\mathrm{C} \equiv \mathrm{CC}\left(\mathrm{N}^{\mathrm{i}} \mathrm{Pr}\right)_{2}+\mathrm{H}\right]^{+}, 343.1(32)\left[\mathrm{M}-2\left(\mathrm{c}-\mathrm{C}_{3} \mathrm{H}_{5}-\mathrm{C} \equiv \mathrm{CC}\left(\mathrm{N}^{\mathrm{i}} \mathrm{Pr}\right)_{2}\right)\right]$,

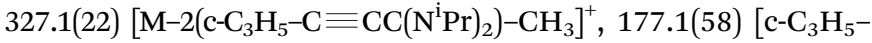
$\left.\mathrm{C} \equiv \mathrm{CC}\left(\mathrm{N}^{\mathrm{i}} \mathrm{Pr}\right)_{2}-\mathrm{CH}_{3}\right]^{+}, 149.1(20)\left[\mathrm{c}-\mathrm{C}_{3} \mathrm{H}_{5}-\mathrm{C} \equiv \mathrm{CC}\left(\mathrm{N}^{\mathrm{i}} \mathrm{Pr}\right)_{2}-\left(\mathrm{c}-\mathrm{C}_{3} \mathrm{H}_{5}\right)\right]^{+}$. IR (KBr): 3653, 3440, 3096, 3015, 2963, 2866, 2608, 2221, 1612, 1466, 1330, 1263, 1210, 1185, 1052, 967, 875, 811, 707, 529, $472 \mathrm{~cm}^{-1}$. Anal. calcd for $\mathrm{C}_{36} \mathrm{H}_{57} \mathrm{~N}_{6} \mathrm{Sm}: \mathrm{C}, 59.70 ; \mathrm{H}, 7.93 ; \mathrm{N}$, $11.60 \%$. Found: C, 59.80; H, 7.83; N, 11.55\%.

$\left[\mathbf{c}-\mathrm{C}_{3} \mathbf{H}_{5}-\mathrm{C} \equiv \mathbf{C C}\left(\mathbf{N}^{\mathrm{i}} \mathbf{P r}\right)_{2}\right]_{3} \mathbf{H o}(\mathbf{2 d})$. A solution of anhydrous $\mathrm{HoCl}_{3}(1.0 \mathrm{~g}, 3.7 \mathrm{mmol})$ in $30 \mathrm{ml}$ of $\mathrm{THF}$ was added to a solution of $1 \mathrm{a}(2.2 \mathrm{~g}, 11.1 \mathrm{mmol})$ in $60 \mathrm{ml}$ of THF. The reaction mixture was heated to $65{ }^{\circ} \mathrm{C}$ for $3 \mathrm{~h}$ and then stirred at r.t. for $12 \mathrm{~h}$. The solvent was removed under vacuum followed by extraction with pentane $2 \times 15 \mathrm{ml}$ to give a clear brightyellow solution. The filtrate was concentrated to $c a .5 \mathrm{ml}$. Crystallization at $-30{ }^{\circ} \mathrm{C}$ for three months afforded $2 \mathrm{~d}$ as pale yellow crystals $(1.2 \mathrm{~g}, 45 \%)$. Due to the strongly paramagnetic nature of the $\mathrm{Ho}^{3+}$ ion, no meaningful ${ }^{1} \mathrm{H}$ NMR data could be obtained. ${ }^{13} \mathrm{C}$ NMR $\left(100.6 \mathrm{MHz}, \mathrm{C}_{6} \mathrm{D}_{6}, 25{ }^{\circ} \mathrm{C}\right): \delta=224.8(\mathrm{NCN})$, $158.8(\mathrm{C} \equiv \mathrm{C}-\mathrm{C}), 62.7(\mathrm{HC}-\mathrm{C} \equiv \mathrm{C}), \quad 50.4\left(\mathrm{CH}-\left(\mathrm{CH}_{3}\right)_{2}\right), \quad 29.8$ $\left(\mathrm{CH}_{3}\right), 26.5\left(\mathrm{CH}_{3}\right), 8.7\left(\mathrm{CH}_{2}, \mathrm{c}-\mathrm{C}_{3} \mathrm{H}_{5}\right), 0.35\left(\mathrm{CH}, \mathrm{c}-\mathrm{C}_{3} \mathrm{H}_{5}\right) . \mathrm{MS}$ (EI, $M=738.39): m / z(\%) 738.5(35)[\mathrm{M}], 723.5(50)\left[\mathrm{M}-\mathrm{CH}_{3}\right]^{+}$, 695.5(32) $\left[\mathrm{M}-2 \mathrm{CH}_{3}\right]^{+}, \quad 547.3(36) \quad\left[\mathrm{M}-\mathrm{c}-\mathrm{C}_{3} \mathrm{H}_{5}-\mathrm{C} \equiv \mathrm{CC}\left(\mathrm{N}^{\mathrm{i}} \mathrm{Pr}\right)_{2}\right]$, 177.1(100) $\left[\mathrm{c}-\mathrm{C}_{3} \mathrm{H}_{5}-\mathrm{C} \equiv \mathrm{CC}\left(\mathrm{N}^{\mathrm{i}} \mathrm{Pr}\right)_{2}-\mathrm{CH}_{3}\right]^{+}, 149.1(43) \quad\left[\mathrm{c}-\mathrm{C}_{3} \mathrm{H}_{5}-\right.$ $\left.\mathrm{C} \equiv \mathrm{CC}\left(\mathrm{N}^{\mathrm{i}} \mathrm{Pr}\right)_{2}-\left(\mathrm{c}-\mathrm{C}_{3} \mathrm{H}_{5}\right)\right]^{+}$. IR (KBr): 3440, 3219, 2964, 2932, 2869, 2227, 1636, 1612, 1486, 1375, 1315, 1260, 1179, 1031, 984, 879, 812, 505, $468 \mathrm{~cm}^{-1}$. Anal. calcd for $\mathrm{C}_{36} \mathrm{H}_{57} \mathrm{HoN}_{6}$ : C, 58.52; H, 7.78; N, 11.38\%. Found: C, 58.75; H, 7.33; N, $11.17 \%$.
4.3 General procedure for the addition of phenylacetylene to $N, N^{\prime}$-diisopropylcarbodiimide catalyzed by $2 \mathrm{a}-\mathrm{d}$.

A $100 \mathrm{ml}$ Schlenk flask was charged with phenylacetylene $(1.40 \mathrm{ml}$, $12.8 \mathrm{mmol}$ ) and $N, N^{\prime}$-diisopropylcarbodiimide (2.0 ml, $\left.12.8 \mathrm{mmol}\right)$ in $20 \mathrm{ml}$ of THF. To the mixture was added the catalyst $(\mathbf{2 a}, \mathbf{2 b}, \mathbf{2 c}$, or $2 \mathrm{~d})(0.5$ or $1.0 \% \mathrm{mmol})$, dissolved in $5 \mathrm{ml}$ of THF. The resulting mixture was stirred at $60{ }^{\circ} \mathrm{C}$ or at room temperature for a fixed time. The solvent was completely removed under vacuum and the product was purified by crystallization from a minimum amount of dry acetonitrile in air to give 3 in yields as shown in Table 2.

\subsection{General procedure for the addition of terminal alkynes to $N, N^{\prime}$-diisopropylcarbodiimide catalyzed by $2 \mathrm{a}$}

A $100 \mathrm{ml}$ Schlenk flask was charged with the terminal alkyne $(1.0 \mathrm{mmol})$ and $N, N^{\prime}$-diisopropylcarbodiimide $(1.0 \mathrm{mmol})$ in $15 \mathrm{ml}$ of THF. To the mixture was added the catalyst $2 \mathrm{a}$ $(0.01 \mathrm{mmol})$, dissolved in $5 \mathrm{ml}$ of THF. The resulting mixture was stirred at $60{ }^{\circ} \mathrm{C}$ for a fixed time, as shown in Table 2. The solvent was removed under vacuum and the product was purified by crystallization from a minimum amount of dry acetonitrile in air. The resulting propiolamidines 3-5 were identified through their ${ }^{1} \mathrm{H}$ and ${ }^{13} \mathrm{C}$ NMR data ( $c f$. ESI $\left.\ddagger\right) .{ }^{7,14}$

\subsection{X-Ray crystallographic studies}

The intensity data of $\mathbf{2 d}$ and $\mathbf{4}$ were collected on a Stoe IPDS $2 \mathrm{~T}$ diffractometer with MoK $\alpha$ radiation. The data were collected with the Stoe $\mathrm{XAREA}^{16}$ program using $\omega$-scans. The space groups were determined with the XRED32 ${ }^{24}$ program. Absorption corrections were applied using the multi-scan method. The structures were solved by direct methods (SHELXS-97) ${ }^{17 a}$ and refined by full matrix least-squares methods on $F^{2}$ using SHELXL-97. ${ }^{17 b}$ Data collection parameters are given in Table 1 .

\section{Acknowledgements}

Financial support by the Otto-von-Guericke-Universität Magdeburg is gratefully acknowledged. Farid M. Sroor is grateful to the ministry of Higher Educational Scientific Research (MHESR), Egypt, and the German Academic Exchange Service (DAAD), Germany, for a PhD scholarship within the German Egyptian Research Long-Term Scholarship (GERLS) program.

\section{References}

1 Recent review articles: (a) F. T. Edelmann, Adv. Organomet. Chem., 2008, 57, 183-352; (b) M. P. Coles, Chem. Commun., 2009, 3659-3676; C. Jones, Coord. Chem. Rev., 2010, 254, 1273-1289; (c) A. A. Trifonov, Coord. Chem. Rev., 2010, 254, 1327-1347; (d) A. A. Mohamed, H. E. Abdou and J. P. Fackler Jr., Coord. Chem. Rev., 2010, 254, 1253-1259; (e) S. Collins, Coord. Chem. Rev., 2011, 255, 118-138; $(f)$ F. T. Edelmann, Adv. Organomet. Chem., 2013, 61, 55-374.

2 (a) F. T. Edelmann, Chem. Soc. Rev., 2009, 38, 2253-2268; (b) F. T. Edelmann, Chem. Soc. Rev., 2012, 41, 7657-7672. 
3 A. Devi, Coord. Chem. Rev., 2013, 257, 3332-3384, and references cited therein.

4 (a) H. Fujita, R. Endo, A. Aoyama and T. Ichii, Bull. Chem. Soc. Jpn., 1972, 45, 1846-1852; (b) G. Himbert, M. Feustel and M. Jung, Liebigs Ann. Chem., 1981, 1907-1927; (c) G. Himbert and W. Schwickerath, Liebigs Ann. Chem., 1984, 85-97; (d) G. F. Schmidt and G. Süss-Fink, J. Organomet. Chem., 1988, 356, 207-211; (e) T.-G. Ong, J. S. O’Brien, I. Korobkov and D. S. Richeson, Organometallics, 2006, 25, 4728; $(f) \mathrm{X}$. Xu, J. Gao, D. Cheng, J. Li, G. Qiang and H. Guo, Adv. Synth. Catal., 2008, 350, 61-64; (g) W. Weingärtner, W. Kantlehner and G. Maas, Synthesis, 2011, 265-272; (h) W. Weingärtner and G. Maas, Eur. J. Org. Chem., 2012, 6372-6382.

5 (a) H. Fujita, R. Endo, K. Murayama and T. Ichii, Bull. Chem. Soc.Jpn., 1972, 45, 1581; (b) W. Ried and M. Wegwitz, Liebigs Ann. Chem., 1975, 89-94; (c) W. Ried and R. Schweitzer, Chem. Ber., 1976, 109, 1643-1649; (d) W. Ried and H. Winkler, Chem. Ber., 1979, 112, 384-388.

6 (a) P. Sienkiewich, K. Bielawski, A. Bielawska and J. Palka, Environ. Toxicol. Pharmacol., 2005, 20, 118-124; (b) T. M. Sielecki, J. Liu, S. A. Mousa, A. L. Racanelli, E. A. Hausner, R. R. Wexler and R. E. Olson, Bioorg. Med. Chem. Lett., 2001, 11, 2201-2204; (c) C. E. Stephens, E. Tanious, S. Kim, D. W. Wilson, W. A. Schell, J. R. Perfect, S. G. Franzblau and D. W. Boykin, J. Med. Chem., 2001, 44, 1741-1748; (d) C. N. Rowley, G. A. DiLabio and S. T. Barry, Inorg. Chem., 2005, 44, 1983-1991.

7 (a) W.-X. Zhang, M. Nishiura and Z. Hou, J. Am. Chem. Soc., 2005, 127, 16788-16789; (b) S. Zhou, S. Wang, G. Yang, Q. Li, L. Zhang, Z. Yao, Z. Zhou and H.-B. Song, Organometallics, 2007, 26, 3755-3761; (c) W.-X. Zhang and Z. Hou, Org. Biomol. Chem.,
2008, 6, 1720-1730; (d) Z. Du, W. Li, X. Zhu, F. Xu and Q. Shen, J. Org. Chem., 2008, 73, 8966-8972; (e) C. N. Rowley, T.-G. Ong, J. Priem, D. S. Richeson and T. K. Woo, Inorg. Chem., 2008, 47, 12024-12031; $(f)$ Y. Wu, S. Wang, L. Zhang, G. Yang, X. Zhu, Z. Zhou, H. Zhu and S. Wu, Eur. J. Org. Chem., 2010, 326-332; (g) F. Zhang, J. Zhang, Y. Zhang, J. Hong and X. Zhou, Organometallics, 2014, 33, 6186-6192.

8 (a) P. Dröse, C. G. Hrib and F. T. Edelmann, J. Organomet. Chem., 2010, 695, 1953-1956; (b) L. Xu, Y.-C. Wang, W.-X. Zhang and Z. Xi, Dalton Trans., 2013, 42, 16466-16469.

9 W. W. Seidel, W. Dachtler and T. Pape, Z. Anorg. Allg. Chem., 2012, 638, 116-121.

10 F. M. A. Sroor, C. G. Hrib, L. Hilfert and F. T. Edelmann, Z. Anorg. Allg. Chem., 2013, 639, 2390-2394.

11 F. M. Sroor, C. G. Hrib, L. Hilfert, P. G. Jones and F. T. Edelmann, J. Organomet. Chem., 2015, 785, 1-10.

12 S. Cotton, Lanthanide and Actinide Chemistry, John Wiley \& Sons, Ltd, Chichester, UK, 2006.

13 G. F. Schmidt and G. Süss-Fink, J. Organomet. Chem., 1988, 356, 207-211.

14 M. Arrowsmith, M. R. Crimmin, M. S. Hill, S. L. Lomas, M. S. Heng, P. B. Hitchcock and G. Kociok-Köhn, Dalton Trans., 2014, 43, 14249-14256.

15 J. H. Freeman and M. L. Smith, J. Inorg. Nucl. Chem., 1958, 7, 224.

16 Stoe, XAREA Program for Xray Crystal Data collection, (XRED32 included in XAREA), Stoe, 2002.

17 (a) G. M. Sheldrick, SHELXL-97 Program for Crystal Structure Refinement, Universität Göttingen, Germany, 1997; (b) G. M. Sheldrick, SHELXS-97 Program for Crystal Structure Solution, Universität Göttingen, Germany, 1997. 